\title{
PENGARUH DANA PIHAK KETIGA DAN NON PERFORMING FINANCING TERHADAP RETURN ON ASSET BANK UMUM SYARIAH DI INDONESIA
}

(PERIODE 2014-2019)

\section{THE EFFECT OF THIRD PARTY FUNDS AND NON PERFORMING FINANCING TOWARDS RETURN ON ASSETS OF SHARIA COMMERCIAL BANKS IN INDONESIA (PERIOD 2014-2019)}

\author{
Sri Ayu Dasari1; Wirman² \\ 1Program Studi Akuntansi Fakultas Ekonomi Universitas Singaperbangsa Karawang, Jl. HS.Ronggo \\ Waluyo, Puseurjaya, Kec. Telukjambe Tim., Kabupaten Karawang, Jawa Barat 41361. \\ 2 Program Studi Akuntansi Fakultas Ekonomi Universitas Singaperbangsa Karawang, Jl. HS.Ronggo \\ Waluyo, Puseurjaya, Kec. Telukjambe Tim., Kabupaten Karawang, Jawa Barat 41361. \\ aKorespondensi: Sri Ayu Dasari, e-mail: 1610631030265@student.unsika.ac.id
}

\begin{abstract}
This study is intended to determine, analyze and describe the influence of Third Party Funds and Non-Performing Financing on Returns on Assets of Sharia Commercial Banks in Indonesia for the 2014-2019 period. The data used in this research is quantitative descriptive. In this study, researchers used saturated sampling in determining samples. This study uses secondary data taken from the annual Islamic financial statements of Islamic Banks in Indonesia which are in the 0JK as well as the official website of each bank in the 2014-2019 period. In the software data analysis process used is Spss 20 which consists of descriptive statistical analysis, classic assumption tests (normality test, multicolliniarity test, autocorrelation test and heteroscedasticity test), multiple linear regression test, and hypothesis testing (determination test, partial t test and simultaneous F test). The results of this study partially, third party funds have no effect on ROA. While non-performing financing has a positive effect on ROA. While simultaneously third-party funds and non-performing financing has a negative and significant effect on return on assets.
\end{abstract}

Keywords: Third-party funds, Non-Performing Financing, Return On Asset

ABSTRAK
Penelitian ini dimaksudkan untuk mengetahui, menganalisis dan mendeskripsikan
pengaruh Dana Pihak Ketiga dan Non-Performing Financing terhadap Return On Asset
Bank Umum Syariah di Indonesia periode 2014-2019. Data yang digunakan pada penelitian
ini yaitu deskriptif kuantitatif. Dalam penelitian ini, peneliti menggunakan sampling jenuh
dalam menentukan sampel. Penelitian ini menggunakan data sekunder yang diambil dari
data laporan keuangan tahunan Bank Umum Syariah di Indonesia yang berada di OJK
maupun website resmi dari masing-masing bank periode 2014-2019. Dalam proses analisis
data software yang digunakan adalah Spss 20 yang terdiri dari analisis statistik deskriptif,
uji asumsi klasik (uji normalitas, multikoleniaritas, autokorelasi dan heteroskedastisitas),
uji regresi linear berganda, dan uji hipotesis (uji determinasi, uji t parsial dan uji F
simultan). Hasil dari penelitian ini secara parsial, DPK tidak terdapat pengaruh terhadap
ROA. Sedangkan NPF memiliki pengaruh positif terhadap ROA. Sedangkan pada uji
simultan DPK dan NPF memiliki pengaruh negatif serta signifikan terhadap ROA.
Kata Kunci: DPK, NPF,ROA
Sri Ayu Dasari. 2020. Pengaruh Dana Pihak Ketiga Dan Non Performing Financing
Terhadap Return On Asset Bank Umum Syariah Di Indonesia (Periode 2014-2019).
Jurnal Nisbah 6 (2): 124-130.




\section{PENDAHULUAN}

Bank merupakan sebuah lembaga keuangan yang pada umumnya didirikan dengan memiliki kewenangan sebagai organisasi ataupun institusi yang memberikan pelayanan berupa kegiatan penyimpanan, peminjaman uang, serta memberikan jasa pengiriman uang. Bank juga merupakan sebuah lembaga keuangan yang dapat mempengaruhi perekonomian baik secara mikro maupun makro. Kegiatan pembangunan perekonomian tidak dapat terlepas dari sektor pebankan yang memiliki pengaruh terhadap pertumbuhan ekonomi sebagai perantara keuangan atau financial intermediary. Di indonesia terdapat dua macam sistem operasional perbankan, yaitu bank konvensional dan bank syariah. Menurut UU No.21 tahun 2008 mengenai perbankan syariah, Bank syariah merupakan bank yang melaksanakan aktifitas usahanya bersumber pada prinsip syariah ataupun hukum islam (www.ojk.go.id). Karena sesuai dengan hukum islam, maka pada bank syariah tidak ada "bunga pinjaman" alias interest rate. Bunga pinjaman diduga riba dan berdosa, sistem yang digunakan bank syariah merupakan "Sistem Bagi Hasil" atau Nisbah yang prosesnya dalam prosesnya diketahui dan disetujui oleh kedua belah pihak yaitu bank dan nasabah.

Dalam perkembangannya perbankan syariah didukung karena perkembangan aset yang terus meningkat setiap tahunnya. perkembangan aset pada perbankan syariah ini salah satunya diakibatkan oleh kenaikan DPK yang dihimpun oleh bank. Dana pihak ketiga adalah penghimpunan dana yang asalnya dari nasabah. Selain membawa keuntungan bagi perbankan dana pihak ketiga juga memiliki risiko yang tinggi yaitu risiko kredit macet atau nonperforming financing. Non-performing financing merupakan kredit macet atau nasabah tidak dapat membayar angsuran sesuai dengan perjanjian. NPF dapat diakibatkan karena banyaknya pembiayaan yang dikeluarkan bank.

Terdapat beberapa penelitian terdahulu yang berhubungan dengan faktor-faktor yang mempengaruhi peningkatan dan penurunan laba Bank Umum Syariah (BUS) di indonesaia. Menurut penelitian husaeni (2017) menjelaskan bahwa variabel DPK secara parsial terdapat pengaruh negatif serta tidak signifikan terhadap variabel ROA. Sedangkan Variabel NPF secara parsial berpengaruh positif dan berpengaruh signifikan terhadap variabel ROA, dengan arah negatif yang berarti ketika nilai NPF semakin tinggi maka semakin rendah nilai ROA. Sedangkan secara keseluruhan variabel DPK dan NPF secara simultan berpengaruh signifikan terhadap variabel ROA.

Menurut penelitian muliawati (2016) DPK terdapat pengaruh negatif serta tidak signifikan terhadap ROA. Hasilnya menunjukkan bahwa DPK berpengaruh negatif terhadap besarnya profitabilitas bank umum syariah, diamana semakin kecil dana pihak ketiga maka profitabilitaspun akan semakin kecil. Sedangkan pada variabel NPF terdapat pengaruh positif serta tidak signifikan terhadap ROA. Hal ini menunjukkan bahwa NPF yang besar tidak secara langsung mempengaruhi penurunan laba pada suatu periode.

Menurut penelitian Fatimatuzzahro (2017) variabel DPK tidak memiliki pengaruh terhadap profitabilitas Return On Asset Bank Umum Syariah ini menunjukkan bahwa kenaikan DPK tidak selalu diiringi dengan naiknya laba. sedangkan untuk variabel NPF terdapat pengaruh negatif dan signifikan terhadap ROA. Jadi semakin kecil tingkat pembiayaan bermasalah atau NPF maka semakin tinggi tingkat profitabilitas ROA yang akan dihasilkan oleh Bank Umum Syariah. Berdasarkan dari penjelasan dari beberapa penelitian terdahulu yang menunjukkan hasil yang tidak konsisten melatar belakangi ketertarikan penulis 
dan yakin bahwa penelitian ini dapat memberikan informasi baru. Sehingga mendorong penulis untuk melakukan penelitian dengan judul Pengaruh Dana Pihak Ketiga (DPK) dan Non-Performing Financing (NPF) terhadap Return On Asset Bank Umum Syariah di indonesia periode 2014-2019.

\section{MATERI DAN METODE}

\section{Return On Asset (ROA)}

Menurut (kasmir, 2014:201) bahwa ROA adalah rasio yang membuktikan hasil atau return atas jumlah aktiva atau aset yang digunakan dalam sebuah perusahaan. Selain itu, ROA juga menunjukkan representasi yang baik atas laba suatu perusahaan karena menunjukkan efektivitasnya terhadap penggunaan aktiva pada perusahaan demi memperoleh laba. Return On Asset dapat dirumuskan sebagai berikut :

$$
R O A=\frac{\text { Laba Sebelum Pajak }}{\text { Total Aktiva }} \times 100 \%
$$

\section{Dana Pihak Ketiga}

DPK merupakan dana yang asalnya dari masyarakat, yakni dari badan usaha ataupun perorangan yang didapatkan bank melalui beragam instrumen produk simpanan yang dimiliki oleh bank tersebut (Hasanudin dan Prihatiningsih, 2010:26). Dana pihak ketiga atau DPK dapat dirumuskan sebagai berikut:

$$
\text { DPK = Giro + Tabungan + Deposito }
$$

\section{Non Performing Financing}

Menurut (prastanto, 2013:8) NPF atau Non Performing Financing adalah jumlah kredit yang bermasalah dan memiliki kemungkinan untuk tidak dapat tertagih. Jika angka NPF semakin tinggi maka dapat menimbulkan akibat buruk bagi perusahaan. Hal tersebut menandakan bahwa jumlah pembiayaan yang bermasalah dalam bank tersebut tinggi, sehingga dapat menimbulkan kerugian bagi bank tersebut serta dapat mengakibatkan jumlah penyaluran pembiayaan menjadi menurun. Berikut ini merupakan rumusan Non performing financing :

$$
N P F=\frac{\text { Total Pembiayaan Bermasalah }}{\text { Total Pembiayaan }} \times 100 \%
$$

\section{HASIL DAN PEMBAHASAN}

\section{Analisis Statistik Deskriptif}

Analisis Deskriptif pada penelitian ini terdapat beberapa nilai yaitu nilai Mean, minimum, maximum dan Standar Deviasi pada setiap variabel. Nilai mean digunakan untuk mencari Rata-rata dari data yang digunakan. Nilai minimum digunakan untuk melihat jumlah atau nilai terkecil dari data tersebut. Nilai maximum digunakan untuk melihat jumlah terbesar dari data tersebut. Sedangkan, untuk mengetahui jumlah penyebaran data terhadap sebuah sampel maka akan digunakan standar deviasi.

Berdasarkan hasil uji analisis statistik deskriptif diatas dijelaskan beberapa data sebagai berikut :

1. Dana Pihak Ketiga

Variabel DPK dengan jumlah data sebanyak 84 data memiliki nilai minimum sebesar 1 , nilai maximum sebesar 99809729 serta Standar deviasi sebesar 21344196,174.

2. Non Performing Financing

Variabel NPF dengan jumlah data sebanyak 84 data memiliki nilai minimum sebesar 0,00 , nilai maximum sebesar 4,97 serta Standar deviasi sebesar 1,71727.

3. Return On Asset (ROA)

Variabel ROA dengan jumlah data sebanyak 84 data memiliki nilai minimum sebesar $-20,13$, nilai maximum sebesar 13,90 serta Standar deviasi sebesar 4,48430.

\section{Uji Asumsi Klasik}

Untuk menghindari atau menimbulkan penyimpangan maka akan dilakukan uji asumsi klasik. Uji asumsi klasik terdiri dari beberapa pengujian, yaitu uji normalitas, uji multikolinearitas, 
uji autokorelasi serta uji heteroskedastisitas.

\section{Uji Normalitas}

Uji Normalitas pada penelitian ini digunakan untuk menguji apakah dalam sebuah uji regresi linear variabel dependen dan independen keduanya memiliki distribusi normal atau tidak. Normal/tidaknya suatu distribusi data ditentukan berdasarkan taraf signifikansi hasil hitung. Uji Normalitas pada penelitian ini merupakan Uji Statistik Kolmogrof-Smirnov. Berikut ini merupakan hasil uji Normalitas :

Berdasarkan hasil pengujian diatas dapat disimpulkaan bahwa ketiga data variabel berdistribusi normal. Hal tersebut dapat diketahui pada tabel 4.2 yang menunjukkan sig sebesar $0.070>0.050$. Hal tersebut menunjukkan bahwa data Dana Pihak Ketiga (X1), Non Performing Financing (X2) dan Return On Asset (Y) Bank Umum Syariah berdistribusi normal.

\section{Uji Autokorelasi}

Uji Autokorelasi digunakan untuk menguji ada atau tidaknya korelasi antara variabel pengganggu pada periode tertentu dengan variabel sebelumnya. Ada tidaknya gejala autokorelasi dapat ditemukan melalui uji Durbin-Watson yaitu dimana jika D-W diantara -2 sampai +2 berarti tidak terjadi autokorelasi.

Berdasarkan tabel nilai D-W (Durbin Watson) adalah sebesar 1,667 dimana nilai D-W berada di antara -2 sampai +2. Hal tersebut berarti tidak terjadi gejala Autokorelasi.

\section{Uji Multikoleniaritas}

Uji multikolinearitas dimaksudkan untuk mengetahui apakah terdapat korelasi atau kesamaan antar variabel bebas atau variabel independen. Adapun hasil uji Multikoleniaritas pada penelitian ini yaitu:

Berdasarkan tabel hasil uji diatas dapat dilihat bahwa setiap variabel memiliki nilai Tolerance sebesar 0,990> 0,100 serta nilai VIF sebesar 1,010 < 10,00. Sehingga, dapat disimpulkan bahwa pada penelitian ini tidak terjadi multikolinearitas.

\section{Uji Heteroskedastisitas}

uji heteroskedastisitas merupakan pengujian perbedaan variance residual suatu periode pengamatan ke periode pengamatan lain. Menurut gozali (2013:142) salah satu cara untuk mengetahui ada atau tidaknya heteroskedastisitas yaitu dengan menggunakan uji glejser. Hasil probabilitas dinyatakan signifikan jika nilai sig > 0,05. Adapun hasil uji Heteroskedastisitas pada penelitian ini yaitu:

Dari Tabel penelitian diatas memperlihatka bahwa DPK (X1) memiliki nilai sig 0,061 $>0,05$ serta Non Performing Financing (X2) memiliki nilai sig 0,672 > 0,05 . Maka dapat diketahui pada penelitian ini tidak terjadi Heteroskedastisitas.

\section{Uji Hipotesis}

\section{Uji T (Parsial)}

Uji $\mathrm{t}$ digunakan untuk mengetahui seberapa besar pengaruh dari masingmasing variabel bebas terhadap variabel terikat. Pengambilan keputusan dilakukan bedasarkan perbandingan nilai $t$ hasil perhitungan ( $t$ hitung) dengan nilai $t$ tabel, dengan tingkat signifikan 5\%. Berdasarkan pengolahan data maka :

a. Diperoleh nilai t hitung sebesar 0,585. Sedangkan, nilai $t$ tabel sebesar 1,98969. Sehingga diperoleh kesimpulan bahwa $\mathrm{H}_{0}$ diterima $\mathrm{H}_{1}$ ditolak. Dapat disimpulkan tidak terdapa pengaruh antara DPK terhadap ROA.

b. Diperoleh nilai t hitung sebesar $-6,077$. Sedangkan, nilai $t$ tabel sebesar 1,98969. Sehingga diperoleh kesimpulan bahwa $\mathrm{H}_{0}$ ditolak $\mathrm{H}_{1}$ diterima. Dapat disimpulkan terdapat pengaruh antara NPF terhadap ROA.

\section{Uji F (Simultan)}

Uji simultan atau uji $F$ ini adalah untuk mengetahui apakah semua variabel independent yang terdapat pada 
penelitian memiliki pengaruh secara bersama-sama terhadap variabel dependen. Pengambilan keputusan dilakukan bedasarkan perbandingan nilai $\mathrm{f}$ hasil perhitungan (f hitung) dengan nilai $f$ tabel, dengan tingkat signifikan 5\%. Berikut ini adalah hasil Uji f (simultan) :

Hasil Uji F variabel DPK (X1) dan NPF (X2) pada tabel diatas, diperoleh nilai $\mathrm{F}$ hitung 18,463 > F tabel 3,11 yang artinya nilai $\mathrm{F}$ hitung lebih tinggi dari $\mathrm{F}$ tabel. Sehingga terdapat pengaruh positif signifikan, sehingga $\mathrm{H}_{0}$ ditolak dan $\mathrm{H}_{3}$ diterima. Dengan demikian, dapat disimpulkan maka DPK (X1) dan NPF (X2) secara simultan berpengaruh positif dan signifikan terhadap ROA (Y).

\section{Uji Determinasi}

Koefisien determinasi $\left(\mathrm{R}^{2}\right)$ digunakan untuk mengukur sejauh mana kemampuan variabel independen dalam menjelaskan variabel dependen.

Pada tabel diatas diketahui nilai koefisien determinasi atau $\mathrm{R}^{2}$ sebesar 0,313 atau $31,3 \%$. Hal ini menyatakan DPK (X1) dan NPF (X2) berpengaruh sebesar 31,3\% kepada ROA (Y). Sedangkan sisanya yaitu $68,7 \%$ dipengaruhi oleh variabel lain yang tidak diteliti dalam penelitian ini.

\section{KESIMPULAN DAN IMPLIKASI}

Penelitian ini bertujuan untuk mengetahui pengaruh Dana Pihak Ketiga (DPK) dan Non Performing Financing (NPF) terhadap Return On Asset (ROA) Bank Umum Syariah di Indonesia Periode 2014-2019. Berdasarkan penelitian yang telah dilakukan, maka kesimpulan yang dapat diambil dari penelitian in adalah sebagai berikut :

1. Variabel Dana Pihak Ketiga (DPK) tidak berpengaruh terhadap Return On Asset (ROA) Bank Umum Syariah Periode 2014-2019. Yang berarti bahwa peningkatan dan penurunan ROA selama periode penelitian tidak mempengaruhi ROA secara signifikan.

2. Variabel Non-Performing Financing (NPF) berpengaruh negatif signifikan terhadap Return On Asset (ROA). Yang artinya semakin rendah NPF maka akan semakin tinggi ROA yang dihasilkan Bank Umum Syariah. Sebaliknya, semakin tinggi tingkat NPF maka akan semakin rendah ROA yang dihasilkan.

3. Variabel DPK dan Non Performing Financing NPF secara simultan berpengaruh positif signifikan kepada ROA Bank Umum Syariah di Indonesia Periode 2014-2019. Pengaruh yang diberikan sebesar 32,3\% dan sisanya dipengaruhi oleh variabel lain yang tidak terdapat dalam penelitian ini.

\section{DAFTAR PUSTAKA}

Gozali, imam. (2013). Aplikasi Analisis Multivariate dengan Program IBM SPSS 21 Update PLS Regresi, Semarang: Badan Penerbit Universitas Diponegoro.

Hanafi, muhamad, dan Halim, abdul. (2012). Analisis Laporan Keuangan. (UPP) STIM YKPN:Yogyakarta.

Kasmir. (2014). Bank dan Lembaga Keuangan Lainnya edisi revisi $2014 . \quad$ PT.Rajagrafindo Persada:jakarta.

Khaerul, Umam. (2013). Manajemen Perbankan Syariah. pustaka setia:Bandung.

Nurhayati sri, dan wasilah. (2014). Akuntansi Syariah di Indonesia edisi 4. Salemba 4:jakarta.

Rochaeti Eti, DKK. (2019). Metodologi Penelitian Bisnis dengan Aplikasi SPSS Edisi 2. Mitra Wacan Media:Bogor.

Sugiyono. (2016). Metode Penelitian Kuantitatif, Kualitatif dan R\&D. Alfabeta:Bandung.

Sujarweni, v, wiratna. (2016). Kupas Tuntas Penelitian Akuntansi 
dengan SPSS. Pustaka www.ojk.com

Baru:Yogyakarta.

\section{LAMPIRAN}

Fatimatuzzahro. (2017). Pengaruh Dana Pihak Ketiga (DPK), Non Performingn Financing (NPF) dan Penempatan Dana Pada Bank Indonesia Terhadap Profitabilitas Bank Umum Syariah periode 20122015. Malang:Jurnal Akuntansi.

Hasanudin, Mohamad dan Prihatiningsih. (2010). Analisis Pengaruh Dana PihakKetiga,Tingkat Suku Bunga,Non Performance Loan (NPL), dan TingkatInflasi Terhadap Penyaluran Kredit Bank Perkreditan Rakyat (BPR) di JawaTengah. Jurnal Teknis Vol. 5 No. 1 April 2010 : 25-31. Semarang: Jurusan Akuntansi Politeknik Semarang.

Prastanto. (2013). Pengaruh Financing to Deposit Ratio (FDR), Non Performing Financing (NPF), Debt to Equity Ratio (DER), Quick Ratio (QR), dan Return on Equity (ROE) terhadap Pembiayaan Mudharabah pada Bank Umum Syariah di Indonesia. Semarang: Skripsi Jurusan Akuntansi Universitas Negeri Semarang.

Sri muliawati. (2016). Faktor-Faktor Penentu Profitabilitas Bank Syariah di Indonesia.Semarang : Skripsi Jurusan Manajemen.

Uus Ahmad Husaeni. (2017). Analisis Pengaruh Dana Pihak Ketiga Dan Non Performing Financing Terhadap Return On Asset Pada BPRS Di Indonesia. Cianjur:Jurnal Ekonomi Syariah.

Undang-Undang Republik Indonesia No.21 tahun 2008 tentang perbankan syariah.

\section{Tabel}

Tabel 1 Analisis Statistik Deskriptif

\begin{tabular}{|l|r|r|r|r|r|}
\hline & $N$ & Minimum & Maximum & Mean & $\begin{array}{c}\text { Std. } \\
\text { Deviation }\end{array}$ \\
\hline DPK & 84 & 1 & 99809729 & 16480165 & 21344196 \\
NPF & 84 & 0 & 4,97 & 2,2338 & 1,71727 \\
ROA & 84 & $-20,13$ & 13,9 & 1,0215 & 4,4843 \\
Valid N & 84 & & & & \\
(listwise) & 84 & & & & \\
\hline
\end{tabular}

Tabel 2 Uji Noermalitas

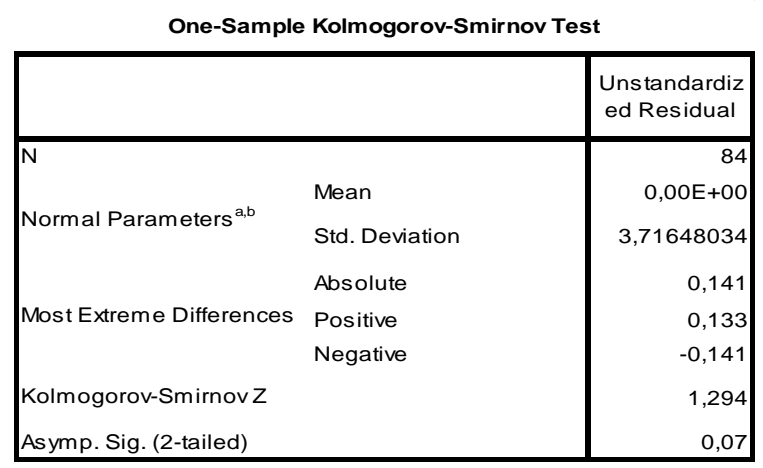

Tabel 3 Uji Autokorelasi

Model Summary

\begin{tabular}{l|r|r|r|r|r|}
\hline Model & R & R Square & $\begin{array}{r}\text { Adjusted } \\
\text { R Square }\end{array}$ & $\begin{array}{r}\text { Std. Error } \\
\text { of the } \\
\text { Estimate }\end{array}$ & $\begin{array}{r}\text { Durbin- } \\
\text { Watson }\end{array}$ \\
\hline 1 &, $560^{\mathrm{a}}$ & 0,313 & 0,296 & 3,76208 & 1,667 \\
\hline
\end{tabular}
a. Predictors: (Constant), NPF, DPK
b. Dependent Variable: ROA

Tabel 4 Uji Multikoleniaritas

Coefficients $^{a}$

\begin{tabular}{|c|c|c|}
\hline \multirow{2}{*}{ Model } & \multicolumn{2}{|c|}{ Collinearity Statistics } \\
\hline & Tolerance & VIF \\
\hline (Con & & \\
\hline $1 \mathrm{DPK}$ & 0,99 & 1,01 \\
\hline NPF & 0,99 & 1,01 \\
\hline
\end{tabular}

a. Dependent Variable: ROA 
Tabel 5 Uji Heteroskedastisitas

\begin{tabular}{|c|c|c|}
\hline \multicolumn{3}{|c|}{ Coefficients $^{\mathrm{a}}$} \\
\hline Model & $\mathrm{T}$ & Sig. \\
\hline (Constant) & 5,063 & 0 \\
\hline 1 DPK & $-1,897$ & 0,061 \\
\hline NPF & 0,424 & 0,672 \\
\hline
\end{tabular}

a. Dependent Variable: ABS_RES

Tabel 6 Uji Regresi Linear Berganda

\begin{tabular}{|c|r|r|r|}
\hline \multirow{2}{*}{ Model } & \multicolumn{2}{|c|}{$\begin{array}{c}\text { Unstandardized } \\
\text { Coefficients }\end{array}$} & \multicolumn{1}{c|}{$\begin{array}{c}\text { Standardized } \\
\text { Coefficients }\end{array}$} \\
\cline { 2 - 4 } & \multicolumn{1}{|c|}{ B } & Std. Error & \multicolumn{1}{c|}{ Beta } \\
\hline (Constant) & 4,115 & 0,726 & \\
1 DPK & 0,011 & 0,019 & \\
NPF & $-1,469$ & 0,242 & 0,054 \\
a. Dependent Variable: ROA & $-0,562$ \\
\hline
\end{tabular}

Tabel 7 Uji T Parsial

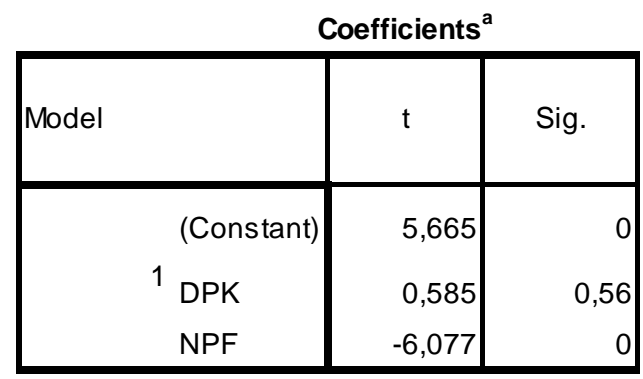

a. Dependent Variable: ROA
Tabel 8 Uji F Simultan ANOVA $^{\mathrm{a}}$

\begin{tabular}{|ll|l|l|}
\hline Model & & $\mathrm{F}$ & Sig. \\
\hline & $\begin{array}{l}\text { Regressio } \\
\mathrm{n}\end{array}$ & 18,463 &, $000^{\mathrm{b}}$ \\
& $\begin{array}{l}\text { Residual } \\
\text { Rotal }\end{array}$ & & \\
& & \\
\hline
\end{tabular}

a. Dependent Variable: ROA

b. Predictors: (Constant), NPF, DPK

Tabel 9 Uji Determinasi $\mathrm{R}^{2}$

Model Summary ${ }^{b}$

\begin{tabular}{|r|r|r|r|}
\hline Model & \multicolumn{1}{|c|}{ R } & R Square & $\begin{array}{r}\text { Adjusted } \\
\text { R Square }\end{array}$ \\
\hline 1 &, $560^{\mathrm{a}}$ & 0,313 & 0,296 \\
\hline
\end{tabular}

a. Predictors: (Constant), NPF, DPK

b. Dependent Variable: ROA 